\title{
Superoxide dismutase (SOD) activity of Ceriops zippeliana in Segara Anakan Cilacap (Indonesia) under heavy metal accumulation
}

\author{
DHUTA SUKMARANI ${ }^{1,2, \vartheta}$, ELLY PROKLAMASININGSIH ${ }^{1}$, AGUS HERY SUSANTO ${ }^{1}$, \\ ERWIN RIYANTO ARDLI ${ }^{1}$, EMING SUDIANA ${ }^{1}$, EDY YANI ${ }^{1}$ \\ ${ }^{1}$ Faculty of Biology, Universitas Jenderal Soedirman. J1. Dr. Soeparno 63, Purwokerto Utara, Banyumas 53122, Central Java, Indonesia. \\ Tel.: +62-281-638794, fax.: +62-281-631700, `email: dhutasukmarani@ummgl.ac.id \\ ${ }^{2}$ Department of Elementary School Teacher Education, Universitas Muhammadiyah Magelang. J1. Tidar 21, Magelang 56125, Central Java, Indonesia
}

Manuscript received: 27 August 2021. Revision accepted: 30 November 2021

\begin{abstract}
Sukmarani D, Proklamasiningsih E, Susanto AH, Ardli ER, Sudiana E, Yani E. 2021. Superoxide dismutase (SOD) activity of Ceriops zippeliana Blume in Segara Anakan Cilacap (Indonesia) under heavy metal accumulation. Biodiversitas 22: $5627-5635$. Ceriops zippeliana Blume is a true mangrove species that occupy habitats exposed to environmental stress, such as salinity and heavy metal contamination, which is the case in Segara Anakan Cilacap, Central Java. Both salinity and heavy metal stress can lead to the production of reactive oxygen species (ROS), which can be detrimental to plants if they are present in excess. Plants have defense mechanisms to prevent excessive ROS, one of which is by the use of superoxide dismutase (SOD) enzyme. This study aims to explain the accumulation of heavy metals $(\mathrm{Pb}, \mathrm{Cd}, \mathrm{Cu}$, and $\mathrm{Zn})$ in $C$. zippeliana as well as the translocation of the metals. In addition, the correlation between heavy metal concentrations and SOD activity in C. zippeliana is reported. Plant samples were randomly collected from Segara Anakan, Cilacap. The analysis was conducted using the bio-concentration factor (BCF), translocation factor (TF), and linear regression in the SPSS program. It was found that $\mathrm{Pb}, \mathrm{Cu}$, and $\mathrm{Zn}$ levels in Segara Anakan Cilacap sediments were still within acceptable limits, while Cd level was moderately polluting. Metal accumulation was higher in the branches of $C$. zippeliana compared to those in roots and leaves. The SOD activity of C. zippeliana in Segara Anakan is seemingly not related to metal contents in plant parts.
\end{abstract}

Keywords: Bio-concentration factor, Ceriops zippeliana, heavy metal accumulation, SOD activity, translocation factor

\section{INTRODUCTION}

Ceriops zippeliana Blume is one of the two Ceriops species (Rhizophoraceae) that occurred in Indonesian mangrove forests, while the other one is $C$. tagal. According to the IUCN Red List, $C$. zippeliana is categorized as Least Concern with decreasing population trend (IUCN 2008). As a member of Rhizophoraceae, which is the most common mangrove family in Indonesia, one area of $C$. zippeliana geographical distribution is Segara Anakan Cilacap, Central Java. This is an estuary or delta located at the mouth of main rivers in Central Java south coast heading to the Indian Ocean. Despite being blocked by Nusakambangan Island from the open ocean, mangroves in Segara Anakan receive the influence of the Indian Ocean currents. C. zippeliana grows in the eastern part of Segara Anakan Cilacap. The mangrove vegetation in this area is pressured by land conversion as well as pollution caused by an oil refinery industry (Supriatna et al. 2018; Sih Piranti et al. 2019; Setyaningrum et al. 2020).

As a true mangrove species, C. zippeliana has extensive morphological, anatomical, physiological and molecular adaptations, allowing growth and development in environments with significant environmental stress, such as salinity and heavy metal (Rodriguez et al. 2012; Srikanth et al. 2016; Surya and Hari 2017). This mechanism can be explained by the buildup of reactive oxygen species (ROS) as one of the metabolic alterations that occur when plants are exposed to salt and heavy metal stress (Hasanuzzaman et al. 2020). Plants produce ROS as a consequence of regular cellular metabolism. However, when there is a disruption in the environment (e.g. increased salinity and pollution), the equilibrium between production and elimination is disturbed. When present in excess, ROS rapidly inactivate enzymes, damage vital cellular organelles in plants, and destroy membranes by inducing the degradation of pigments, proteins, lipids, and nucleic acids, ultimately resulting in cell death (Karuppanapandian et al. 2011). Raja et al. (2017) found that ROS can disturb normal metabolism by causing oxidative damage to lipids, proteins, and nucleic acids, as well as impairing membrane function (Hasanuzzaman et al. 2020).

Not all ROS are free radicals. Some ROS are radicals, such as superoxide anion $\left(\mathrm{O}_{2}^{-}\right)$, hydroperoxyl radical $\left(\mathrm{HO}_{2}\right)$, alkoxy radical (RO) and hydroxyl radicals $\left(\mathrm{OH}^{-}\right)$, while others are non-radicals, such as hydrogen peroxide $\left(\mathrm{H}_{2} \mathrm{O}_{2}\right)$ and singlet oxygen $\left(\mathrm{O}_{2}\right)$. Superoxide radicals are extremely harmful when combined with hydrogen peroxide $\left(\mathrm{H}_{2} \mathrm{O}_{2}\right)$ because they form hydroxyl radicals $\left(\mathrm{OH}^{-}\right)$ (Hasanuzzaman et al. 2020).

Plants have defense mechanisms to deal with environmental stress. Activating antioxidant enzymes is one of the antioxidant defense strategies in plants. Superoxide dismutase (SOD), catalase (CAT), and glutathione peroxidase are some of the enzymes involved. SOD catalyzes the dismutation of superoxide radicals $\left(\mathrm{O}_{2}{ }^{-}\right)$ into $\mathrm{H}_{2} \mathrm{O}_{2}$ and $\mathrm{O}_{2}$; catalase degrades $\mathrm{H}_{2} \mathrm{O}_{2}$ into water and oxygen; and glutathione peroxidase catalyzes the reduction 
of $\mathrm{H}_{2} \mathrm{O}_{2}$ to $\mathrm{H}_{2} \mathrm{O}$ using reduced glutathione $(\mathrm{GSH})$ and oxidized glutathione (GSSG) as cofactors (Hasanuzzaman et al. 2017). SOD is considered to be at the forefront of overcoming oxidative stress due to its position as the first enzyme to catalyze superoxide radicals $\left(\mathrm{O}^{2-}\right)$ (Ighodaro and Akinloye 2018).

There has been no investigation on heavy metal bioaccumulation and its correlation with SOD activity in $C$. zippeliana from Segara Anakan Cilacap so far. As a result, such studies must be conducted to provide information on the long-term conservation of $C$. zippeliana as well as the management of estuaries and coastal areas. This study aims to elucidate the accumulation of heavy metal $\mathrm{Pb}, \mathrm{Cd}, \mathrm{Cu}$, and $\mathrm{Zn}$ in $C$. zippeliana, as well as the translocation of the metals in $C$. zippeliana. The correlation between heavy metal concentrations and SOD activity in C. zippeliana is also investigated.

\section{MATERIALS AND METHODS}

\section{Study area and period}

Samples were collected randomly from the eastern section of Segara Anakan lagoon, Cilacap District, Central Java, Indonesia at geographical position of $7^{\circ} 68^{\prime} 91^{\prime \prime} \mathrm{S}$ $108^{\circ} 99^{\prime} 35^{\prime \prime}$ E. They were collected at three different sites along the estuary, from the outside to the inside, across the oil refinery industries (Figure 1). The sampling was accomplished in July 2020.

\section{Procedures}

Sample collection and identification

Sediments as well as roots, branches, and leaves of $C$. zippeliana were taken randomly from three different sites in the canal. Every sample was weighed up to $500 \mathrm{~g}$. The samples were placed in zip lock bags, labeled, and stored in an icebox. The Flora of Java by Backer and Bakhuizen van Den Brink (1963) determination book was used for identification.

\section{Heavy metal content analysis}

Analyzing the metal contents of $\mathrm{Cu}, \mathrm{Zn}, \mathrm{Pb}$, and $\mathrm{Cd}$ in sediments and plant parts began with drying the sample in an oven for 6 hours at $80^{\circ} \mathrm{C}$ for plants and $105^{\circ} \mathrm{C}$ for sediments. The aqua regia method $\left(\mathrm{HNO}_{3}: \mathrm{HCl}=1: 3\right)$ was used to digest $5 \mathrm{~g}$ of the sample, which was heated at $100^{\circ} \mathrm{C}$ for 8 hours until the volume reached $1 \mathrm{~mL}$. Before heating, hydrofluoric acid (HF) was added to the sediment samples. The sample was then cooled to room temperature and transferred to a $100 \mathrm{~mL}$ volumetric flask, where aquabidest were added to the mark - then filtered using $0.40 \mu \mathrm{m}$ pore filter paper. AAS (Atomic Absorption Spectroscopy) was used to determine metal concentration (Takarina and Pin 2017). The recovery rates of heavy metals in CRM are listed in Table 1.

Table 1. Recovery rates of heavy metal concentrations measured in certified reference material and standard deviation

\begin{tabular}{cccc}
\hline Element & $\begin{array}{c}\text { Certified value } \\
\text { GSD-10 } \\
(\mathbf{m g} / \mathbf{k g})\end{array}$ & $\begin{array}{c}\text { Measured value } \\
(\mathbf{N}=\mathbf{3}) \\
(\mathbf{m g} / \mathbf{k g})\end{array}$ & $\begin{array}{c}\text { Recovery } \\
\text { rate } \\
(\mathbf{\%})\end{array}$ \\
\hline $\mathrm{Cu}$ & $22.6 \pm 0.6$ & $20.33 \pm 4.72$ & 90 \\
$\mathrm{Zn}$ & $46 \pm 1.3$ & $32.22 \pm 0.20$ & 70 \\
$\mathrm{~Pb}$ & $27 \pm 1$ & $27.38 \pm 0.86$ & 101 \\
$\mathrm{Cd}$ & $1.12 \pm 0.05$ & $1.73 \pm 0.04$ & 154
\end{tabular}

SEGARA ANAKAN CILACAP MAP

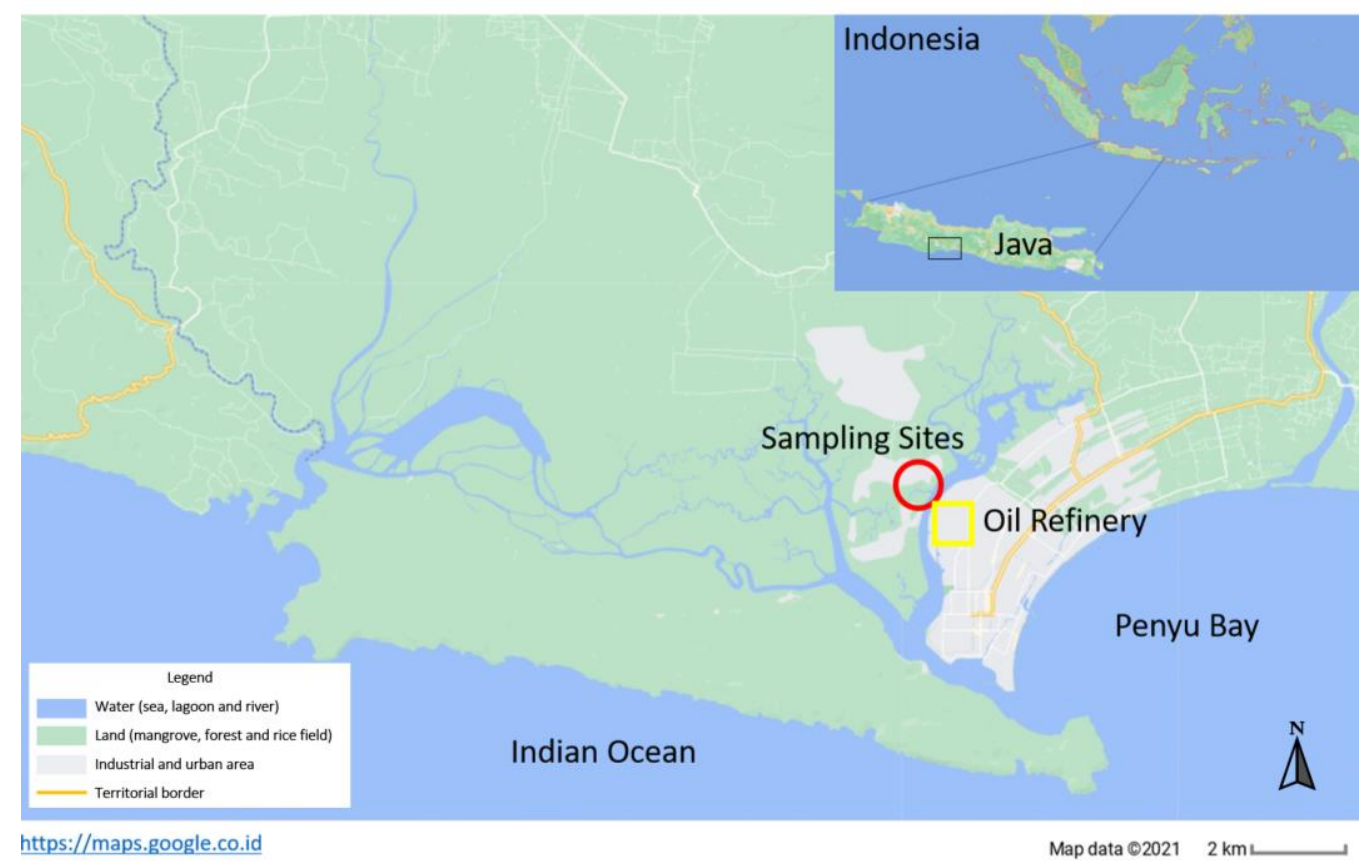

Figure 1. Map of the sampling sites in Segara Anakan lagoon, Cilacap District, Central Java, Indonesia 
Superoxide dismutase (SOD) activity assay

The SOD activity assay started with extraction of roots, leaves, and branches that have been dried in an oven at $70^{\circ} \mathrm{C}$ for 48 hours before being mashed. Extraction was performed with a $96 \%$ ethanol solvent using the maceration process. SOD activity assay was performed according to the RANSOD Manual by Randox Laboratories, with the following modifications: $20 \mu \mathrm{L}$ of sample was added to a combination of 1,000 $\mu \mathrm{L} \mathrm{R1} \mathrm{(1} \mathrm{bottle} \mathrm{of} \mathrm{mixed} \mathrm{substrate}$ R1a with $20 \mu \mathrm{L}$ Buffer R1b) and $100 \mu \mathrm{L} \mathrm{R} 2$ (1 vial of xanthine oxidase dissolved with $10 \mathrm{~mL}$ of distilled water). The absorbance of the reaction mixture was measured at $\lambda$ $520 \mathrm{~nm}$ (Randox Laboratories 2009).

\section{Data analysis}

\section{Bio-concentration factor $(B C F)$}

Bio-concentration factor $(\mathrm{BCF})$ can be used to determine the value of metal bioaccumulation $(\mathrm{Pb}, \mathrm{Cd}, \mathrm{Cu}$, and $\mathrm{Zn}$ ) in plant sections of $C$. zippeliana, either by active or passive accumulation. BCF is the ratio of individual metal concentration in the tissue $\left(\mathrm{C}_{\text {tissues }}\right)$ to that in the sediment $\left(\mathrm{C}_{\text {sediment }}\right)$ (Takarina and Pin 2017).

$$
\mathrm{BCF}=\mathrm{C}_{\text {tissues }} / \mathrm{C}_{\text {sediment }}
$$

\section{Translocation factor (TF)}

The metal translocation process among parts of the $C$. zippeliana plant was calculated using the translocation factor (TF), which is the ratio of metal concentration between two plant parts (Takarina and Pin, 2017):

$$
\begin{aligned}
& \mathrm{TF}_{\text {root to branch }}=\mathrm{C}_{\text {branch }} / \mathrm{C}_{\text {root }} \\
& \mathrm{TF}_{\text {root to leaves }}=\mathrm{C}_{\text {leaves }} / \mathrm{C}_{\text {root }} \\
& \mathrm{TF}_{\text {branch to leaves }}=\mathrm{C}_{\text {leaves }} / \mathrm{C}_{\text {branch }}
\end{aligned}
$$

\section{Superoxide dismutase (SOD) activity}

Pearson correlation in the SPSS program was utilized to establish the correlation between metal concentration and SOD activity (Bujang and Baharum 2016).

\section{RESULTS AND DISCUSSION}

\section{Heavy metal concentrations in sediments}

Lead $(\mathrm{Pb})$ concentration in the Segara Anakan sediments was found ranging from 26.53 to $28.24 \mathrm{mg} / \mathrm{kg}$ (Table 2) with an average of $27.38 \mathrm{mg} / \mathrm{kg}$ (Table 3). These are still within the tolerable levels compared to those in other mangrove locations (Table 2). In natural environment, it is available at $70 \mathrm{mg} / \mathrm{kg}$ or lower, and could be toxic to plants when presents at 100 to $500 \mathrm{mg} / \mathrm{kg}$ (Kabata-Pendias and Pendias 2000). Meanwhile, the Pb concentration is also still much below the standard for agricultural soils in some countries, i.e. $80 \mathrm{mg} / \mathrm{kg}$ (EPMC, China), $200 \mathrm{mg} / \mathrm{kg}$ (CME, Canada), $200 \mathrm{mg} / \mathrm{kg}$ (TMS Tanzania), $200 \mathrm{mg} / \mathrm{kg}$ (USEPA, USA), $300 \mathrm{mg} / \mathrm{kg}$ (EPAA, Australia), $530 \mathrm{mg} / \mathrm{kg}$ (EEA, Netherlands), $1,000 \mathrm{mg} / \mathrm{kg}$ (EEA Germany) (He et al. 2015), and $4,000 \mathrm{mg} / \mathrm{kg}$ (NOAA) (Buchman 1999).
$\mathrm{Pb}$ is a toxic element that causes various physiological consequences, including decreased seed germination, root elongation, lower biomass, inhibition of chlorophyll biosynthesis, mineral feeding and enzymatic responses. The severity of these effects depends on the length of exposure, the stage of plant development, the organ understudy, and the $\mathrm{Pb}$ concentration involved. $\mathrm{Pb}$ enters plants mostly through roots, notably the apoplast route or calcium ion channels (Pourrut et al. 2011). On the other hand, $\mathrm{Pb}$ enters plants in little amounts through leaves (Ghosh and Roy 2019). The sampling site in Segara Anakan Cilacap was located less than $1 \mathrm{~km}$ from an oilrefinery area with various pollutants, including air pollution. As one of the pollutants from the oil refinery industry, $\mathrm{Pb}$ can also enter the leaves through the air, along with other heavy metals (De Agostini et al. 2020), but it is not used in plant physiological processes. This could explain why the concentration of $\mathrm{Pb}$ in the leaves is higher than that of $\mathrm{Zn}$ or other metals.

The concentration of cadmium $(\mathrm{Cd})$ in the Segara Anakan sediments in this study ranged from 1.69 to 1.77 $\mathrm{mg} / \mathrm{kg}$ (Table 2) with an average of $1.73 \mathrm{mg} / \mathrm{kg}$ (Table 3), which is higher than those of natural levels. Nevertheless, the $\mathrm{Cd}$ concentrations obtained are not excessively high or moderate compared to those in other places (Table 2). $\mathrm{Cd}$ values of $0.1-1 \mathrm{mg} / \mathrm{kg}$ are found naturally in soil (Smolders and Mertens 2013). Standards for Cd in agricultural soils from numerous countries are $0.11 \mathrm{mg} / \mathrm{kg}$ (US EPA USA), 0.3-0.6 mg/kg (EPMC China), $1 \mathrm{mg} / \mathrm{kg}$ (TMS Tanzania), 3 $\mathrm{mg} / \mathrm{kg}$ (EPAA Australia), $3 \mathrm{mg} / \mathrm{kg}$ (CME Canada), 13 $\mathrm{mg} / \mathrm{kg}$ (EEA Netherlands), $50 \mathrm{mg} / \mathrm{kg}$ (EEA Germany) (He et al. 2015), and 100-300 mg/kg (NOAA) (Buchman 1999). This means that $\mathrm{Cd}$ concentration in the Segara Anakan sediments is higher than natural values and exceeds American, Chinese, and Tanzanian standards, but still below the standard of others.

$\mathrm{Cd}$ is a non-essential element that has deleterious impact on plant growth and development. Because of the generation of reactive oxygen species (ROS), $\mathrm{Cd}$ can cause metabolic problems in plants by inhibiting nitrogen uptake and transport, reducing plant growth, lowering chlorophyll and carotenoid content, and inhibiting photosynthesis. $\mathrm{Cd}$ enters plant tissues through the soil and water, along with other nutrients, which are absorbed through roots, transported through xylem, and stored in various tissues (Ghosh and Roy 2019). Cd is generally accumulated in vacuoles or cell walls. This accumulation was identified as one of the $\mathrm{Cd}$ detoxification and tolerance mechanisms (Uddin et al. 2021). It restricts and limits the free circulation of $\mathrm{Cd}$ ions in the cytosol. Like other metal ions, $\mathrm{Cd}$ can be taken from the air, deposited on the leaf surface, and subsequently absorbed into plant tissues (Ghosh and Roy 2019).

Copper $(\mathrm{Cu})$ concentrations in mangrove sediments in Segara Anakan ranged from 15.61 to $25.06 \mathrm{mg} / \mathrm{kg}$ (Table 2) with an average of $20.33 \mathrm{mg} / \mathrm{kg}$ (Table 3), which are still moderate when compared to those in some other places (Table 2). $\mathrm{Cu}$ standards in agricultural soils are $100 \mathrm{mg} / \mathrm{kg}$ (EPAA Australia), $150 \mathrm{mg} / \mathrm{kg}$ (CME Canada), 150-300 $\mathrm{mg} / \mathrm{kg}$ (EPMC China), $190 \mathrm{mg} / \mathrm{kg}$ (EEA Netherlands), 200 
$\mathrm{mg} / \mathrm{kg}$ (EEA Germany), $200 \mathrm{mg} / \mathrm{kg}$ (TMS Tanzania), 270 $\mathrm{mg} / \mathrm{kg}$ (US EPA USA) (He et al. 2015), and 10,000-25,000 $\mathrm{mg} / \mathrm{kg}$ (NOAA) (Buchman 1999). Thus, it could be said that $\mathrm{Cu}$ levels in Segara Anakan sediments are still below the standards for agricultural soils in the countries.

Since required in enzyme systems related to photosystem II electron transport, mitochondrial and chloroplast reactions, carbohydrate metabolism, cell wall lignification, and protein synthesis, $\mathrm{Cu}$ is an essential element for plant growth. This metal, in particular, serves as a cofactor for metalloenzymes (Kumar et al. 2021). Cu can be toxic to plant growth if the concentration level in the sediment exceeds $800 \mathrm{mg} / \mathrm{kg}$ (Marques et al. 2018). This is about 40 times higher than those observed in Segara Anakan sediments (Table 3).

Compared to the other metals, the concentration of Zinc $(\mathrm{Zn})$ in the sediment, roots, and branches of C. zippeliana in Segara Anakan was found highest. This is as Marschner (2011), who claims that $\mathrm{Zn}$ is the second most prevalent transition metal in living organisms after iron $(\mathrm{Fe})$ (Balafrej et al. 2020). Zn concentrations in Segara Anakan sediments ranged from 32.03 to $32.43 \mathrm{mg} / \mathrm{kg}$ (Table 2) with an average of $32.23 \mathrm{mg} / \mathrm{kg}$ (Table 3). This concentration has not exceeded its normal level, and it is also quite modest compared to other locations (Table 2). Natural levels in soils and rocks are typically between 10 and $300 \mathrm{mg} / \mathrm{kg}$, while those in rivers are often less than $0.2 \mathrm{mg} / \mathrm{kg}$ (Noulas et al. 2018). Zn standards for agricultural soils in some countries are $150 \mathrm{mg} / \mathrm{kg}$ (TMS Tanzania), $200 \mathrm{mg} / \mathrm{kg}$ (EPAA Australia), 200-300 mg/kg (EPMC China), 500 $\mathrm{mg} / \mathrm{kg}$ (CME Canada), $600 \mathrm{mg} / \mathrm{kg}$ (EEA Germany), 720 $\mathrm{mg} / \mathrm{kg}$ (EEA Netherlands), $1,100 \mathrm{mg} / \mathrm{kg}$ (US EPA USA) (He et al. 2015), and 7,000-38,000 $\mathrm{mg} / \mathrm{kg}$ (NOAA) (Buchman 1999). This indicates that Zn levels in Segara Anakan sediments are less than the standards.

$\mathrm{Zn}$ is found in soil due to the pedogenetic process of washing the source rock (Wuana and Okieimen 2011). This metal influences cell division and differentiation, as well as plant development, reproduction, and cell signaling which includes DNA replication, transcription, and protein synthesis. Many enzymes, such as carbonic anhydrase, carboxypeptidase, and $\mathrm{Zn}$-superoxide dismutase, require $\mathrm{Zn}$ as a cofactor (Balafrej et al. 2020).

According to NOAA, the sequence of metal concentrations from high to low is $\mathrm{Cu} / \mathrm{Zn}>\mathrm{Pb}>\mathrm{Cd}$, implying that $\mathrm{Cu}$ may be greater than $\mathrm{Zn}$, or that $\mathrm{Zn}$ may be greater than $\mathrm{Cu}$. In addition, $\mathrm{Pb}$ concentration comes after $\mathrm{Cu}$ or $\mathrm{Zn}$, and $\mathrm{Cd}$ comes last (Buchman 1999). Sediment metal concentrations in Segara Anakan were $\mathrm{Zn}>\mathrm{Pb}>\mathrm{Cu}>\mathrm{Cd}$. The $\mathrm{Pb}$ concentration is still below the international standard set by various countries and the NOAA, as previously stated. Even so, because the $\mathrm{Pb}$ concentration was higher than the $\mathrm{Cu}$ concentration, it can be said that $\mathrm{Pb}$ in Segara Anakan was relatively high.

\section{Heavy metal concentrations in plant parts compared to sediments}

It can be seen from the analysis of sediment samples from the three different sites and a total of nine samples of C. zippeliana plant parts that a relatively similar distribution of elements in sediments, roots, and branches were observed, i.e. $\mathrm{Zn}>\mathrm{Pb}>\mathrm{Cu}>\mathrm{Cd}$. However, this was not the case with leaves, where $\mathrm{Pb}>\mathrm{Zn}>\mathrm{Cu}>\mathrm{Cd}$ (Table 3). The average concentration level of individual metal in the plant parts of C. zippeliana showed a relatively similar pattern, in which branches had the highest metal concentrations followed sequentially by roots and leaves. This demonstrates that roots, as opposed to branches, have a stronger potential to absorb metals rather than accumulate them (Takarina and Pin 2017). On the other hand, the branch tissue can store more metals, including nonessential metals (Arumugam et al. 2018). This could be related to a long-term accumulation of metals in the branches (Marchiol et al. 2004). Roots are more susceptible to metals than shoots are, because roots are the first organs to come into touch with metals (in the soil), and they accumulate metals in higher proportions than shoots do (Tiryakioglu et al. 2006; Hilmi et al. 2017).

Toxicity and even the usefulness of an element for plants are both subjective. Plants can demonstrate a phytotoxic response or tolerance with the buildup of metals in their bodies, as indicated by Mishra et al. (2006), depending on their demands, endurance, and environment. Phytotoxic responses such as chlorosis, necrosis, wilting, decreased growth, lower biomass (Kumar et al. 2016), stunting, and decreased crop yields, have all been observed. Meanwhile, the tolerance response can be indicated by enzyme activity (Hasanuzzaman et al. 2020) or detoxifying mechanisms, such as selective metal absorption, excretion, synthesis of metal compounds with specific ligands, and metal compartmentalization (Pourrut et al. 2011).

Table 2. Heavy metal concentrations in sediment samples from eastern part of Segara Anakan compared to other locations

\begin{tabular}{lcccccl}
\hline \multirow{2}{*}{ Locations } & \multirow{2}{*}{$\mathbf{N}$} & \multicolumn{4}{c}{ Heavy metal concentrations (mg/kg) } & \multirow{2}{*}{ References } \\
\cline { 3 - 6 } & & $\mathbf{P b}$ & $\mathbf{C d}$ & $\mathbf{C u}$ & $\mathbf{Z n}$ & \\
Segara Anakan Cilacap & 3 & $26.53-28.24$ & $1.69-1.77$ & $15.61-25.06$ & $32.03-32.43$ & This study \\
Segara Anakan Cilacap & 34 & - & - & $16-84$ & $39-480$ & (Syakti et al. 2015) \\
Segara Anakan Cilacap & 6 & $3.96-21.99$ & $0.43-2.21$ & - & - & (Hidayati et al. 2014) \\
Jakarta Bay & 4 & $<$ LOD-357 & $<$ LOD-13 & $<$ LOD-515 & - & (Siregar et al. 2016) \\
Coast of Red Sea & 15 & $13.5-230$ & ND-5.48 & $45.5-280$ & $3.95-275$ & (Usman et al. 2013) \\
Hainan Island, Cina & 12 & $11-19$ & $0.06-0.13$ & $9-18$ & $32-57$ & (Qiu et al. 2011) \\
Kathmandu, Nepal & 60 & $20.96-31.81$ & $0.23-0.30$ & $25.39-27.91$ & $35.15-59.70$ & (Yan et al. 2012) \\
\hline
\end{tabular}

Note: the values are based on the range from minimum to maximum concentration from each study. (N: number of samples; -: not measured) 
Table 3. Heavy metal concentrations in sediments and Ceriops zippeliana samples from eastern part of Segara Anakan

\section{Bio-concentration factor $(B C F)$}

Based on the average value of $\mathrm{BCF}, \mathrm{Zn}>\mathrm{Pb}>\mathrm{Cd}>\mathrm{Cu}$ sequence of concentration levels in the roots with an average value of less than 1 was observed. Different sequence of $\mathrm{Zn}>\mathrm{Cd}>\mathrm{Cu}>\mathrm{Pb}$ with an average value of more than 1 was found in the branches, while $\mathrm{Pb}>\mathrm{Cd}>\mathrm{Zn}>\mathrm{Cu}$ with an average value of less than 1 was obtained in the leaves (Table 4). The Bioconcentration factor value is divided into 3 (three) categories; with a $\mathrm{BCF}$ value $>1$ is classified as an accumulator, $\mathrm{BCF}$ value $=1$ can be categorized as an indicator, while $\mathrm{BCF}$ value $<1$ is classified as an excluder (Mastaller 1996 in Isroni et al. 2020). Each species has a different ability to absorb heavy metals from its environment. Several other mangrove species have a high capacity to absorb heavy metals from their environment. Even Xylocarpus granatum, Sonneratia alba, Rhizophora apiculata, Bruguiera gymnorrhiza, B. parviflora, C. tagal, and Lumnitzera racemosa can have a BCF value of more than 2 (Analuddin et al. 2017). In addition, the older tissue can store more metal, and the BCF value can be greater (Mejías et al. 2013). In this study, the $\mathrm{BCF}$ values indicate the ability of $C$. zippeliana to store metals absorbed from the environment in its plant tissues. It is likely that in $C$. zippeliana the ability to store metals in branches is higher than that in roots and leaves.
Table 4. Bio-concentration factor (BCF) of heavy metals in Ceriops zippeliana samples from eastern part of Segara Anakan

\begin{tabular}{lccccc}
\hline \multicolumn{2}{c}{ Plant parts } & Pb & Cd & Cu & Zn \\
\hline Root & Min & 0.25 & 0.06 & 0.33 & 0.27 \\
& Max & 1.07 & 1.18 & 0.50 & 1.12 \\
\multirow{4}{*}{ Branch } & Mean & 0.60 & 0.53 & 0.42 & 0.79 \\
& Min & 1.03 & 1.09 & 0.15 & 0.39 \\
& Max & 1.12 & 1.34 & 2.86 & 2.98 \\
Leaves & Mean & 1.07 & 1.21 & 1.09 & 1.30 \\
& Min & 0.48 & 0.37 & 0.10 & 0.07 \\
& Max & 0.50 & 0.45 & 0.15 & 0.31 \\
& Mean & 0.49 & 0.41 & 0.13 & 0.21 \\
\hline
\end{tabular}

\section{Translocation factor $(T F)$}

Translocation factor (TF) is used to analyze the movement of elements from roots to shoots and to evaluate the phytoextraction capability of plants by comparing metal concentrations in leaves, branches, and roots (Marchiol et al. 2004). Figure 2 shows that the highest TF value was found from roots to branches with an average of more than 1 , where $\mathrm{Cu}>\mathrm{Cd}>\mathrm{Pb}>\mathrm{Zn}$ was observed. In contrast, the TF values from roots to leaves and from branches to leaves with an average of less than 1 respectively were obtained. This indicates that metal translocation from roots to stems is better than that from roots to leaves, where the speed of translocation is affected by the transport network capillary system (Takarina and Pin 2017). It is also revealed that metal accumulates continuously in branches throughout time and that branches have a higher phytoextraction potential than those of roots and leaves (Marchiol et al. 2004).

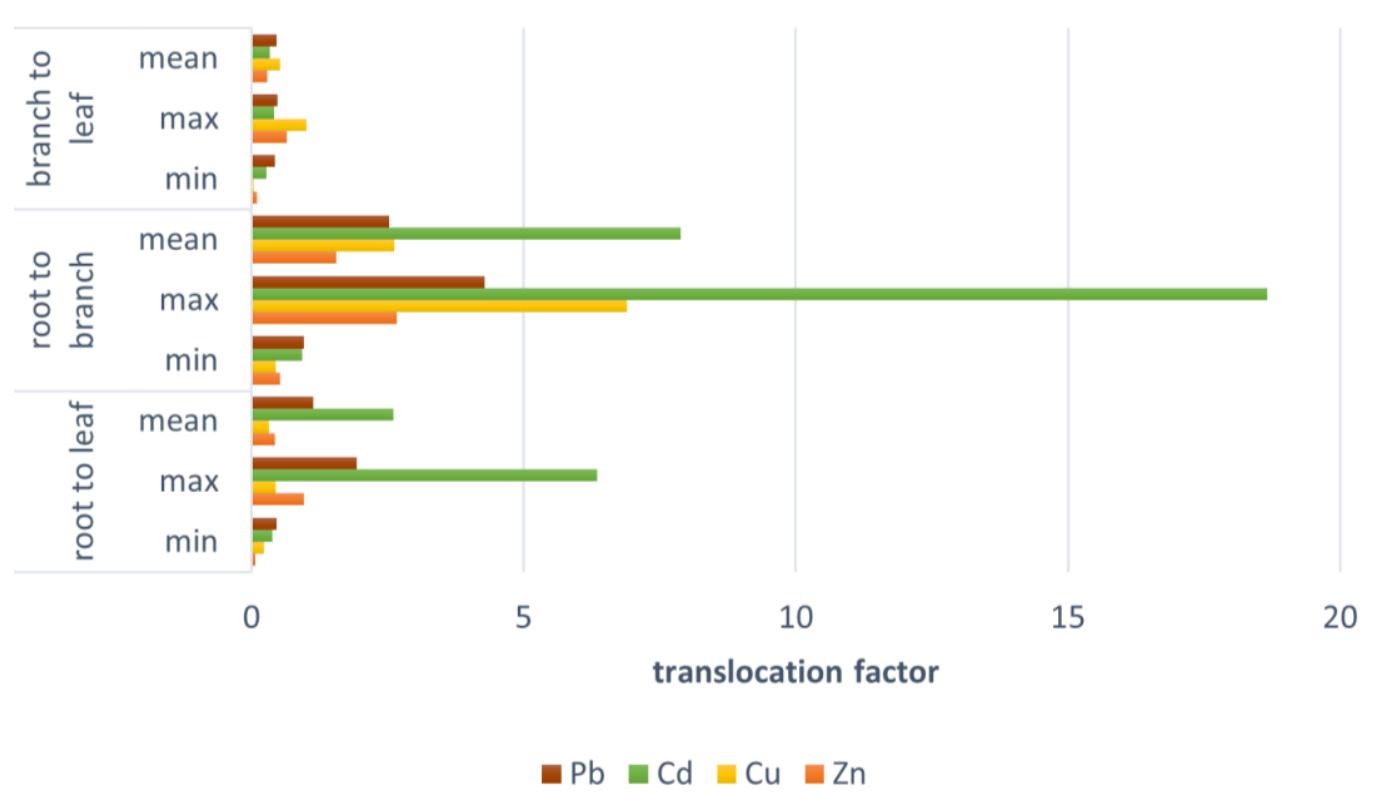

Figure 2. Diagram of each metal's translocation factors (TF) in plant sections of Ceriops zippeliana 
$\mathrm{Zn}$ was detected at the highest concentration in the roots and branches of $C$. zippeliana. The high $\mathrm{Zn}$ concentration in the roots and branches may be due to its high concentration in the sediments (Thanh-Nho et al. 2018). Each metal concentration was found higher in the roots than in the leaves. This may occur because roots are the organs that interact first with various elements and metals in sediments. Moreover, the highest metal concentration in the branches suggests that $C$. zippeliana could accumulate metal in tissues (Jadia and Fulekar 2008).

The concentration of $\mathrm{Pb}$ in the leaves was found higher than the other three metals. This can be the case because $\mathrm{Pb}$ enters the plant through the leaves from the air, especially since the sample was taken from near an oil refinery, contributing to $\mathrm{Pb}$ contamination through the air. On the other hand, $\mathrm{Cu}$ can be bound to organic debris, reducing its availability in leaves (Lacerda et al. 1993). $\mathrm{Cu}$ and $\mathrm{Zn}$ concentrations in leaves are thought to be lower than that of $\mathrm{Pb}$ because they are widely used in biological metabolic activities (Lacerda et al. 1993; Arumugam et al. 2018).

C. zippeliana was shown to have phytoremediation capability by accumulating most metals in its branches as can be seen from BCF and TF values obtained in this study. This is in accordance with Jadia and Fulekar (2008), suggesting that tolerance to heavy metal, high metal accumulation ability, abundant root system, and high bioaccumulation factor are some of the characteristics for plants that can be applied for phytoremediation. Lacerda et al. (1993) also noted that BCF might be used to determine how well plants adapt to their environments.

\section{Correlation between metal concentration and SOD} activity in Ceriops zippeliana

It was found that branches showed the highest SOD enzyme activity $(155.57 \pm 15.66 \mathrm{U} / \mathrm{ml})$, followed by leaves $(104.2 \pm 30.07 \mathrm{U} / \mathrm{ml})$ and the roots $(98.7 \pm 33.90 \mathrm{U} / \mathrm{ml})$. The significance value of the p-value for each element was 0.064 for $\mathrm{Pb}$; 0.070 for $\mathrm{Cd} ; 0.967$ for $\mathrm{Cu}$; and 0.0992 for $\mathrm{Zn}$ when it was correlated to metal concentration in individual part of the plant using Pearson correlation. All the four metal elements showed a p-value greater than 0.05 , implying no significant relationship between metal concentrations in plant parts and SOD enzyme activity overall. Several previous studies have also shown that enzyme activity can increase or decrease in response to metal treatment (Tiryakioglu et al. 2006; Hu et al. 2007).

The activity of the SOD can decrease or increase depending on the amount of $\mathrm{Pb}$ present. In this case, individual plant has also unique response. SOD activity can increase and decrease in aquatic plants Potamogeton crispus due to differences in $\mathrm{Pb}$ treatment (Hu et al. 2007). When compared to control plants, SOD activity decreased at $10-20 \mathrm{mg} / \mathrm{L} \mathrm{Pb}$ concentrations but increased again at 50 $\mathrm{mg} / \mathrm{L} \mathrm{Pb}$ concentrations. Lethal $\mathrm{Pb}$ concentrations in $P$. crispus are estimated to be between 10 and $15 \mathrm{mg} / \mathrm{L}$. Mishra et al. (2006) reported different responses in the aquatic plant Ceratophyllum, showing that Ceratophyllum could show an increase in SOD as a positive tolerance response at moderate $\mathrm{Pb}$ concentrations (1-25 $\mu \mathrm{m})$ and that SOD activity decreased with increasing duration and $\mathrm{Pb}$ concentration $(100 \mu \mathrm{m})$ (Hu et al. 2007). Thus, it can be deduced that each plant has a tolerance for different $\mathrm{Pb}$ levels, which affects the SOD activity. Similarly, $\mathrm{Pb}$ levels in the branches of $C$. zippeliana from Segara Anakan were relatively high (Figure 3), which corresponded to high SOD activity. Meanwhile, even though the $\mathrm{Pb}$ concentration in roots was higher than that in leaves, SOD activity in roots was lower than that in leaves. The ability of $\mathrm{Pb}$ to induce ROS accumulation might cause a change in the activity of the SOD enzyme.

It is widely accepted that $\mathrm{Cd}$ toxicity causes oxidative stress in plants by causing the formation of ROS (Tiryakioglu et al. 2006). Cd can cause oxidative stress in plants by increasing ROS production (Luo et al. 2011). Plants can be protected from oxidative damage by increased SOD activity after being exposed to low $\mathrm{Cd}$ doses. SOD activity, on the other hand, decreases when exposed to high doses of Cd (Tiryakioglu et al. 2006). As a comparison, in leaves and roots of B. gymnorrhiza and $K$. candel with treatment $1 \mathrm{HM}(1.0 \mathrm{mg} / \mathrm{l} \mathrm{Pb}$, and $0.2 \mathrm{mg} / \mathrm{l} \mathrm{Cd}$ and $\mathrm{Hg}$ ), 5HM (five times higher), 10HM (ten times higher), and 15HM (fifteen times higher). Leaf SOD activity decreased at $1 \mathrm{HM}$ for both species compared to the control, but increased with heavy metal concentration. SOD activity in B. gymnorrhiza peaked at 5HM and decreased to control levels at $15 \mathrm{HM}$, but remained higher than control at 10HM (Zhang et al. 2007). SOD activity in $K$. candel peaked at $10 \mathrm{HM}$ and remained significantly higher than controls at 15HM. Different results were obtained in sorghum with SOD activity decreasing at moderate $\mathrm{Cd}$ concentrations $(25 \mu \mathrm{M})$ and increasing at higher $\mathrm{Cd}$ concentrations $(50-100 \mu \mathrm{M})$ (Hassan et al. 2020). In the other hand, $C$. decandra still has lower SOD activity than Thespesia populneoides and $S$. apetala, with an average of 1.49 (Vadlapudi and Naidu 2009). As a result, the level of $\mathrm{Pb}$ and $\mathrm{Cd}$ concentrations that can inhibit or increase SOD enzyme activity in plants, particularly $C$. zippeliana, is unspecified.

Aside from antioxidant enzymes, plants have other defense mechanisms. For example, immobilization or detention of $\mathrm{Cd}$ in the cell wall to prevent $\mathrm{Cd}$ from entering the cell, compartmentalization or accumulation of $\mathrm{Cd}$ in vacuoles to limit circulation and prevent $\mathrm{Cd}$ from entering the cytosol, exclusion or release of $\mathrm{Cd}$ through cell membrane diffusion, and formation of $\mathrm{Cd}$ into complex compounds in the form of phytochelatins, as well as to prevent the free circulation of $\mathrm{Cd}$ in the organ. Metalbinding to sulfhydryl or thiol groups (-SH) is an example of phytochelatin because $\mathrm{Pb}$ and $\mathrm{Cd}$ have a high affinity for sulfhydryl groups. However, due to the inhibition of functional sulfhydryl groups in the action of SOD enzymes, this binding can alter antioxidant activity (Patra et al. 2011). It is possible that the sulfhydryl groups binding to $\mathrm{Pb}$ or Cd caused the decrease in SOD enzyme activity in $C$. zippeliana in this study. 

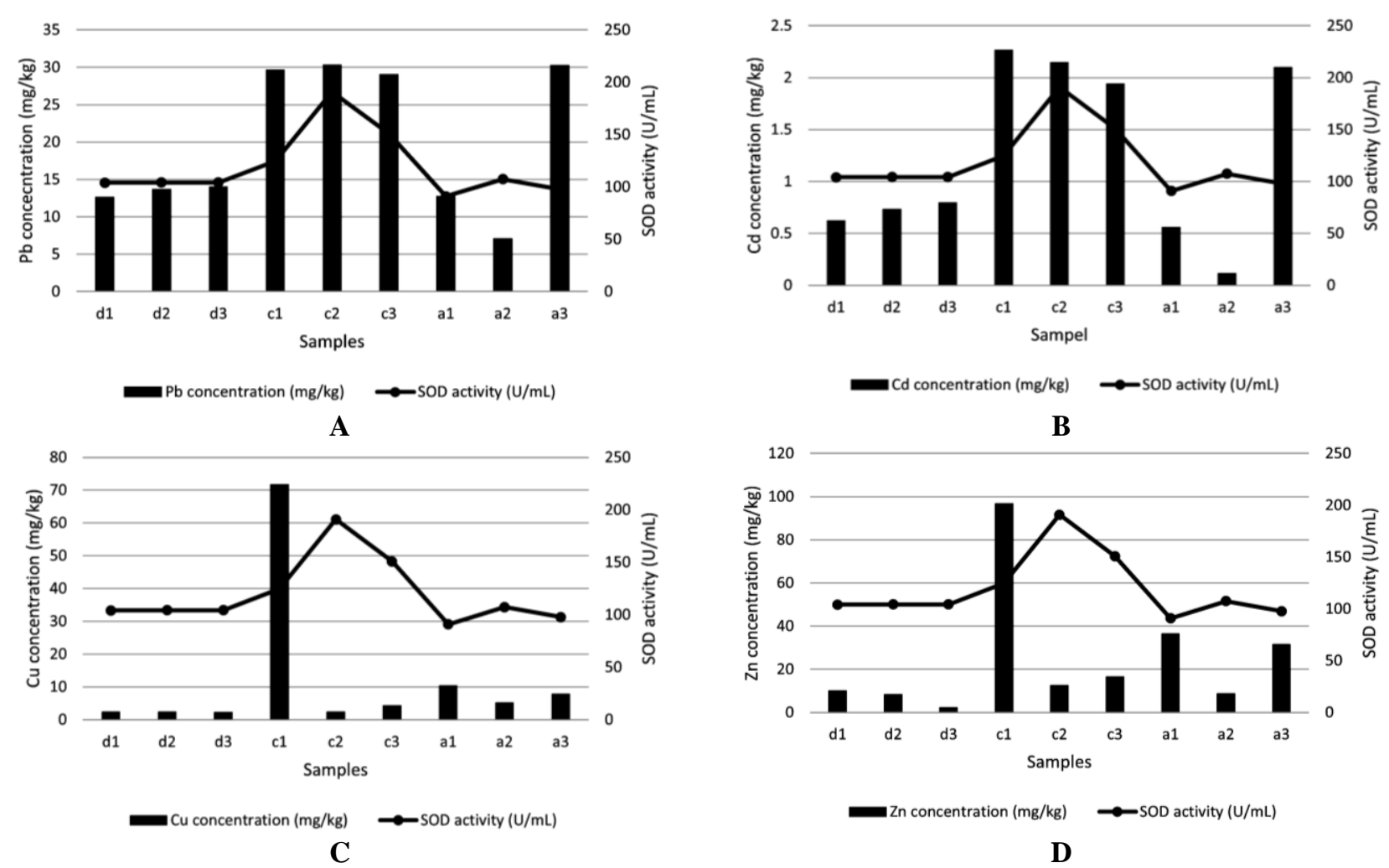

Figure 3. Correlation between heavy metal concentration and SOD activity in Ceriops zippeliana. A. Pb, B. Cd, C. Cu, D. Zn

$\mathrm{Cu}$ content is also reported as one of the factors influencing the increase in SOD activity. $\mathrm{Cu}$ content in leaves and roots increased with increasing $\mathrm{Cu}$ concentration due to treatment. It also affects the decrease in $\mathrm{Fe}$ and $\mathrm{Mn}$ content in leaves and roots (Karimi et al. 2012). The increase in $\mathrm{Cu}$ concentration was also accompanied by an increase in SOD activity active against ROS (Karimi et al. 2012). In this case, $\mathrm{Cu}$ acts as a cofactor for the SOD enzyme. Although $\mathrm{Cu}$ is an essential metal needed by plants, $\mathrm{Cu}$ can also be harmful to plants in high concentrations. $\mathrm{Cu}$ content that inhibits SOD activity in Jatropha curcas L. was $800 \mu \mathrm{mol}$ (Gao et al. 2008), therefore it may be stated that $\mathrm{Cu}$ in $C$. zippeliana from Segara Anakan has not reached the level that inhibits SOD activity.

With an increase in $\mathrm{Zn}$ concentration in plants, the activity of SOD can increase. This can be explained by the fact that the presence of $\mathrm{Zn}$ as a cofactor is required for SOD (Castillo-González et al. 2018). SOD can work adequately when $\mathrm{Zn}$ is available in appropriate amounts. In order to increase enzyme activity, the duration of $\mathrm{Zn}$ treatment is also essential (Bharti et al. 2014). Similarly, a $\mathrm{Zn}$ deficit might reduce SOD activity. In this case, the $\mathrm{Zn}$ deficit mainly influences the decline in $\mathrm{Cu} / \mathrm{ZnSOD}$ activity, but $\mathrm{Zn}$ deficiency has little effect on MnSOD activity. Even if the $\mathrm{Zn}$ concentration is the same, the symptoms of deficiency can be of varying severity. This is due to a differential in the quantity of $\mathrm{Zn}$ that is physiologically active instead of the overall $\mathrm{Zn}$ concentration (Cakmak et al. 1997).

Similarly, it was found in this study that the increase in SOD activity of $C$. zippeliana could be due to the availability of sufficient amounts of $\mathrm{Zn}$. However, it could also decrease due to a lack of physiologically active $\mathrm{Zn}$. Furthermore, according to Balafrej et al. (2020), because $\mathrm{Zn}$ and $\mathrm{Cd}$ have competitive interactions, the presence of $\mathrm{Zn}$ in organisms can prevent $\mathrm{Cd}$ toxicity. On the other hand, if an organism is lacking in $\mathrm{Zn}, \mathrm{Cd}$ toxicity might rise, which is, of course, linked to an increase or decrease in SOD activity. Other factors that are thought to influence SOD activity include salinity (Carrasco-Ríos and Pinto 2014), pH (Kushkevych et al. 2014), or the presence of inhibitors such as $\mathrm{H} 2 \mathrm{O} 2$ compounds (Hasanuzzaman et al. 2020), KCN, methyl viologen (Takagi et al. 2016), or nitration reactions that may occur in the plant body (Holzmeister et al. 2015).

It could be concluded from this study that the levels of $\mathrm{Pb}, \mathrm{Cu}$, and $\mathrm{Zn}$ metals in the sediments of Segara Anakan Cilacap were still within acceptable limits, while that of $\mathrm{Cd}$ was considered at polluting level though not excessive. $C$. zippeliana in Segara Anakan showed branches as the most metal accumulating parts compared to roots and leaves. The SOD activity in $C$. zippeliana from Segara Anakan showed a complex interaction with some factors other than metal concentrations in plant sections. 


\section{ACKNOWLEDGEMENTS}

The authors are sincerely grateful to the Institute for Research and Public Service Universitas Jenderal Soedirman Purwokerto for funding this project under the scheme of Riset Institutional Unsoed 2021 (Chancellor's Decree number of 1070/UN23/HK.02/2021). High appreciation is also addressed to the Faculty of Biology, Universitas Jenderal Soedirman, Banyumas Indonesia and Universitas Muhammadiyah Magelang, Indonesia for all facilities provided.

\section{REFERENCES}

Analuddin K, Sharma S, Jamili, Septiana A, Sahidin I, Rianse U, Nadaoka K. 2017. Heavy metal bioaccumulation in mangrove ecosystem at the coral triangle ecoregion, Southeast Sulawesi, Indonesia. Mar Pollut Bull 125 (1-2): 472-480. DOI: 10.1016/j.marpolbul.2017.07.065.

Arumugam G, Rajendran R, Ganesan A, Sethu R. 2018. Bioaccumulation and translocation of heavy metals in mangrove rhizosphere sediments to tissues of Avicenia marina - a field study from tropical mangrove forest. Environ Nanotechnol Monit Manag 10: 272-279. DOI: 10.1016/j.enmm.2018.07.005.

Balafrej H, Bogusz D, Triqui, ZElA, Guedira A, Bendaou N, Smouni A Fahr M. 2020. Zinc hyperaccumulation in plants: A review. Plants 9 (5): 562. DOI: 10.3390/plants9050562.

Bharti K, Pandey N, Shankhdhar D, Srivastava PC, Shankhdhar SC. 2014 Effect of different zinc levels on activity of superoxide dismutases and acid phosphatases and organic acid exudation on wheat genotypes. Physiol Mol Biol Plants 20 (1): 41-48. DOI: 10.1007/s12298-013-0201-7.

Booher LE, Zampello FC. 1994. Lead exposure in a petroleum refinery during maintenance and repair activities. Appl Occup Environ Hyg 9 (2): 125-131. DOI: 10.1080/1047322X.1994.10388283.

Buchman MF. 1999. NOAA Screening Quick Reference Tables - Squirts. In: National Oceanic and Atmospheric Administration.

Bujang MA, Baharum N. 2016. Sample size guideline for correlation analysis. World J Soc Sci Res 3 (1): 37-46. DOI: 10.22158/wjssr.v3n1p37.

Cakmak I, Ozturk L, Eker S, Torun B, Kalfa HI, Yilmaz A. 1997. Concentration of zinc and activity of copper/zinc-superoxide dismutase in leaves of rye and wheat cultivars differing in sensitivity to zinc deficiency. J Plant Physiol 151 (1): 91-95. DOI: 10.1016/S0176-1617(97)80042-9.

Carrasco-Ríos L, Pinto M. 2014. Effect of salt stress on antioxidant enzymes and lipid peroxidation in leaves in two contrasting corn, "Lluteño" and "Jubilee." Chil J Agric Res 74 (1): 89-95. DOI: 10.4067/S0718-58392014000100014.

De Agostini A, Cortis P, Cogoni A. 2020. Monitoring of air pollution by moss bags around an oil refinery: A critical evaluation over 16 years. Atmosphere 11 (3): 272. DOI: 10.3390/atmos11030272.

Drazkiewicz M, Skórzyńska-Polit E, Krupa, Z. 2004. Copper-induced oxidative stress and antioxidant defence in Arabidopsis thaliana. BioMetals $\quad 17 \quad$ (4): $379-387 . \quad$ DOI: 10.1023/B:BIOM.0000029417.18154.22.

Gao S, Yan R, Cao M, Yang W, Wang S, Chen F. 2008. Effects of copper on growth, antioxidant enzymes and phenylalanine ammonia-lyase activities in Jatropha curcas L. seedling. Plant Soil Environ 54 (3): 117-122. DOI: 10.17221/2688-pse.

Ghosh R, Roy S. 2019. Cadmium toxicity in plants: Unveiling the physicochemical and molecular aspects. In Cadmium Tolerance in Plants: Agronomic, Molecular, Signaling, and Omic Approaches. Elsevier Inc.

Hasanuzzaman M, Bhuyan MHMB, Zulfiqar F, Raza A, Mohsin SM, Al Mahmud J, Fujita M, Fotopoulos V. 2020. Reactive oxygen species and antioxidant defense in plants under abiotic stress: Revisiting the crucial role of a universal defense regulator. Antioxidants 9 (8): 681 . DOI: 10.3390/antiox9080681.

Hasanuzzaman M, Nahar K, Anee TI, Fujita M. 2017. Glutathione in plants: Biosynthesis and physiological role in environmental stress tolerance. Physiol Mol Biol Plants 23 (2): 249-268. DOI: 10.1007/s12298-017-0422-2.

Hassan MJ, Raza MA, Rehman SU, Ansar M, Gitari H, Khan I, Wajid M, Ahmed M, Shah GA, Peng Y, Li Z. 2020. Effect of cadmium toxicity on growth, oxidative damage, antioxidant defense system and cadmium accumulation in two sorghum cultivars. Plants 9 (11): 1575 . DOI: $10.3390 /$ plants9111575.

He Z, Shentu J, Yang X, Baligar VC, Zhang T, Stoffella PJ. 2015. Heavy metal contamination of soils: Sources, indicators, and assessment. J Environ Indic 9: 17-18.

Hidayati NV, Siregar AS, Sari LK, Putra GL, Hartono, Nugraha IP, Syakti AD. 2014. Pendugaan tingkat kontaminasi logam berat $\mathrm{Pb}, \mathrm{Cd}$ dan Cr pada air dan sedimen di perairan Segara Anakan, Cilacap. OmniAkuatika XIII (18): 30-39. DOI: 10.20884/1.oa.2014.10.1.14. [Indonesian]

Hilmi E, Siregar AS, Syakti AD. 2017. Lead (Pb) distribution on soil, water and mangrove vegetation matrices in eastern part of Segara Anakan Lagoon, Cilacap. Omni-Akuatika 13 (2): 25-38. DOI: 10.20884/1.oa.2017.13.2.83

Holzmeister C, Gaupels F, Geerlof A, Sarioglu H, Sattler M, Durner J, Lindermayr C. 2015. Differential inhibition of arabidopsis superoxide dismutases by peroxynitrite-mediated tyrosine nitration. J Exp Bot 66 (3): 989-999. DOI: 10.1093/jxb/eru458.

Hu JZ, Shi GX, Xu QS, Wang X, Yuan QH, Du KH. 2007. Effects of $\mathrm{Pb}^{2+}$ on the active oxygen-scavenging enzyme activities and ultrastructure in Potamogeton crispus leaves. Russ J Plant Physiol 54 (3): 414-419. DOI: $10.1134 / \mathrm{S} 1021443707030181$

Ighodaro OM, Akinloye OA. 2018. First line defence antioxidantssuperoxide dismutase (SOD), catalase (CAT) and glutathione peroxidase (GPX): Their fundamental role in the entire antioxidant defence grid. Alexandria J Med 54 (4): 287-293. DOI: 10.1016/j.ajme.2017.09.001

Isroni W, Bahri AS, Maulida N. 2020. Assessing bioaccumulation of $\mathrm{Pb}$ and $\mathrm{Cu}$ of mangroves in Sarinah island, Indonesia. Ecol Environ Conserv 26 (4): 1584-1586.

IUCN. 2008. Ceriops zippeliana. https://www.iucnredlist.org/species/178812/7614493

Jadia CD, Fulekar, MH. 2008. Phytotoxicity and remediation of heavy metals by fibrous root grass (sorghum). J Appl Biosci 10 (1): 491499.

Kabata-Pendias A, Pendias H. 2000. Trace Elements in Soils and Plants (3rd Ed.). CRC Press, Boca Raton, Florida.

Karimi P, Khavari-Nejad RA, Niknam V, Ghahremaninejad F, Najafi F. 2012. The Effects of excess copper on antioxidative enzymes, lipid peroxidation, proline, chlorophyll, and concentration of $\mathrm{Mn}, \mathrm{Fe}$, and $\mathrm{Cu}$ in Astragalus neo-mobayenii. Sci World J 2012: 615670. DOI: 10.1100/2012/615670

Karuppanapandian T, Moon JC, Kim C, Manoharan K, Kim W. 2011. Reactive oxygen species in plants: Their generation, signal transduction, and scavenging mechanisms. Aust J Crop Sci 5 (6): 709 725.

Kozlowski TT, Pallardy SG. 2002. Acclimation and adaptive responses of woody plants to environmental stresses. Bot Rrev 68 (2): 270-334.

Kumar D, Singh D, Barman S, Kumar N. 2016. Heavy metal and their regulation in plant system: An overview. In: Singh A, Prasad SM, Singh RP (Eds.). Plant Responses to Xenobiotics. Springer.

Kumar V, Pandita S, Singh Sidhu GP, Sharma A, Khanna K, Kaur P, Bali AS, Setia R. 2021. Copper bioavailability, uptake, toxicity and tolerance in plants: A comprehensive review. Chemosphere 262: 127810. DOI: $10.1016 /$ j.chemosphere.2020.127810.

Kushkevych IV, Antonyak HL, Fafula RV. 2014. Activity and kinetic properties of superoxide dismutase of the sulfate-reducing bacteria Desulfovibrio piger Vib -7 and Desulfomicrobium sp. Rod-9. Microbiol Biotechnol 4: 26-35. DOI: 10.18524/23074663.2014.4(28).48409.

Lacerda LD, Carvalho CEV, Tanizaki KF, Ovalle ARC, Rezende CE. 1993. The biogeochemistry and trace metals distribution of mangrove rhizospheres. Biotropica 25 (3): 252. DOI: 10.2307/2388783.

Loring DH, Rantala, RTT. 1992. Manual for the geochemical analyses of marine sediments and suspended particulate matter. Earth Sci Rev 32 (4): 235-283. DOI: 10.1016/0012-8252(92)90001-A

Luo H, Li H, Zhang X, Fu J. 2011. Antioxidant responses and gene expression in perennial ryegrass (Lolium perenne L.) under cadmium stress. Ecotoxicology 20 (4): 770-778. DOI: 10.1007/s10646-0110628-y 
Marchiol L, Assolari S, Sacco P, Zerbi G. 2004. Phytoextraction of heavy metals by canola (Brassica napus) and radish (Raphanus sativus) grown on multicontaminated soil. Environ Pollut 132 (1): 21-27. DOI: 10.1016/j.envpol.2004.04.001.

Marques DM, Veroneze Júnior V, da Silva AB, Mantovani JR, Magalhães PC, de Souza TC. 2018. Copper Toxicity on photosynthetic responses and root morphology of Hymenaea courbaril L. (Caesalpinioideae). Water Air Soil Pollut 229: 138. DOI: 10.1007/s11270-018-3769-2.

Mejías CL, Musa JC, Otero J. 2013. Exploratory evaluation of retranslocation and bioconcentration of heavy metals in three species of mangrove at Las Cucharillas Marsh, Puerto Rico. J Trop Life Sci 3 (1): 14-22. DOI: 10.11594/jtls.03.01.03.

Mishra S, Srivastava S, Tripathi RD, Kumar R, Seth CS, Gupta DK. 2006. Lead detoxification by coontail (Ceratophyllum demersum L.) involves induction of phytochelatins and antioxidant system in response to its accumulation. Chemosphere 65 (6): 1027-1039. DOI: 10.1016/j.chemosphere.2006.03.033.

Noulas C, Tziouvalekas M, Karyotis T. 2018. Zinc in soils, water and food crops. J Trace Elem Med Biol 49: 252-260. DOI: 10.1016/j.jtemb.2018.02.009.

Patra RC, Rautray AK, Swarup D. 2011. Oxidative stress in lead and cadmium toxicity and its amelioration. Vet Med Intl 2011: 457327. DOI: $10.4061 / 2011 / 457327$.

Pourrut B, Shahid M, Dumat C, Winterton P, Pinelli E. 2011. Lead uptake, toxicity, and detoxification in plants. Rev Environ Contam Toxicol 213: 113-136. DOI: 10.1007/978-1-4419-9860-6_4.

Qiu YW, Yu KF, Zhang G, Wang WX. 2011. Accumulation and partitioning of seven trace metals in mangroves and sediment cores from three estuarine wetlands of Hainan Island, China. J Hazard Mater 190: 631-638. DOI: 10.1016/j.jhazmat.2011.03.091.

Raja V, Majeed U, Kang H, Andrabi KI, John R. 2017. Abiotic stress: Interplay between ROS, hormones and MAPKs. Environ Exp Bot 137: 142-157. DOI: 10.1016/j.envexpbot.2017.02.010.

Randox Laboratories L. 2009. RANSOD Manual. Randox Laboratories Ltd.

Rodriguez HG, Mondal B, Sarkar NC, Ramaswamy A, Rajkumar D, Mait RK. 2012. Comparative morphology and anatomy of few mangrove species in Sundarbans, West Bengal, India and its adaptation to saline habitat. Intl J Bio-Resource Stress Manag 3 (1): 1-17.

Siregar TH, Priyanto N, Putri AK, Rachmawati N, Triwibowo R, Dsikowitzky L, Schwarzbauer J. 2016. Spatial distribution and seasonal variation of the trace hazardous element contamination in Jakarta Bay, Indonesia. Mar Pollut Bull 110 (2): 634-646. DOI: 10.1016/j.marpolbul.2016.05.008.

Smolders E, Mertens J. 2013. Cadmium. In: Alloway BJ (Ed.). Heavy Metals in Soils: Trace Metals and Metalloids in Soils and Their Bioavailability. Springer.
Srikanth S, Lum SKY, Chen Z. 2016. Mangrove root: Adaptations and ecological importance. Trees Struct Funct 30 (2): 451-465. DOI: 10.1007/s00468-015-1233-0.

Surya S, Hari N. 2017. Leaf anatomical adaptation of some true mangrove species in Kerala. Intl J Pharm Sci Res 2 (3): 11-14.

Syakti AD, Demelas C, Hidayati NV, Rakasiwi G, Vassalo L, Kumar N, Prudent P, Doumenq P. 2015. Heavy metal concentrations in natural and human-impacted sediments of Segara Anakan Lagoon, Indonesia. Environ Monit Assess 187: 4079. DOI: 10.1007/s10661-014-4079-9.

Takagi D, Takumi S, Hashiguchi M, Sejima T, Miyake C. 2016. Superoxide and singlet oxygen produced within the thylakoid membranes both cause photosystem I photoinhibition. Plant Physiol 171 (3): 1626-1634. DOI: 10.1104/pp.16.00246.

Takarina ND, Pin TG. 2017. Bioconcentration factor (BCF) and Translocation factor (TF) of heavy metals in mangrove trees of Blanakan fish farm. Makara J Sci 21 (2): 77-81. DOI: 10.7454/mss.v21i2.7308.

Thanh-Nho N, Marchand C, Strady E, Vinh TV, Nhu-Trang, TT. 2018. Metals geochemistry and ecological risk assessment in a tropical mangrove (Can Gio, Vietnam). Chemosphere 219: 365-382. DOI: 10.1016/j.chemosphere.2018.11.163.

Tiryakioglu M, Eker S, Ozkutlu F, Husted S, Cakmak I. 2006. Antioxidant defense system and cadmium uptake in barley genotypes differing in cadmium tolerance. J Trace Elem Med Biol 20 (3): 181-189. DOI: 10.1016/j.jtemb.2005.12.004.

Uddin MM, Chen Z, Huang L. 2021. Cadmium accumulation, subcellular distribution and chemical fractionation in hydroponically grown Sesuvium portulacastrum [Aizoaceae]. PLoS One 15: e244085 DOI: 10.1371/journal.pone.0244085.

Usman ARA, Alkredaa RS, Al-Wabel MI. 2013. Heavy metal contamination in sediments and mangroves from the Coast of Red Sea: Avicennia marina as potential metal bioaccumulator. Ecotoxicol Environ Saf 97: 263-270. DOI: 10.1016/j.ecoenv.2013.08.009.

Vadlapudi V, Naidu KC. 2009. Available online through evaluation of antioxidant potential of selected mangrove Plants. J Pharm Res 2 (11): 1742-1745.

Wuana RA, Okieimen FE. 2011. Heavy metals in contaminated soils: A review of sources, chemistry, risks and best available strategies for remediation. ISRN Ecol 2011: 402647. DOI: 10.5402/2011/402647.

Yan X, Zhang F, Zeng C, Zhang M, Devkota LP, Yao T. 2012. Relationship between heavy metal concentrations in soils and grasses of roadside farmland in Nepal. Intl J Environ Res Public Health 9 (9): 3209-3226. DOI: 10.3390/ijerph9093209.

Zhang FQ, Wang YS, Lou ZP, Dong JDe. 2007. Effect of heavy metal stress on antioxidative enzymes and lipid peroxidation in leaves and roots of two mangrove plant seedlings (Kandelia candel and Bruguiera gymnorrhiza). Chemosphere 67: 44-50. DOI: 10.1016/j.chemosphere.2006.10.007. 